\title{
Cyclin-Dependent Kinase 8
}

National Cancer Institute

\section{Source}

National Cancer Institute. Cyclin-Dependent Kinase 8. NCI Thesaurus. Code C95299.

Cyclin-dependent kinase 8 ( $464 \mathrm{aa}, \sim 53 \mathrm{kDa}$ ) is encoded by the human CDK8 gene. This protein plays a role in the modulation of both transcription and protein phosphorylation. 